\title{
Variability of species of Babesia Starcovici, 1893 in three sympatric ticks (Ixodes ricinus, Dermacentor reticulatus and Haemaphysalis concinna) at the edge of Pannonia in the Czech Republic and Slovakia
}

\author{
Markéta Rybářová ${ }^{,}$, Michaela Honsová ${ }^{1}$ Ivo Papoušek $^{1,2}$ and Pavel Široký ${ }^{1,2}$ \\ ${ }^{1}$ Department of Biology and Wildlife Diseases, Faculty of Veterinary Hygiene and Ecology, University of Veterinary and \\ Pharmaceutical Sciences Brno, Brno, Czech Republic; \\ ${ }^{2}$ CEITEC-Central European Institute of Technology, University of Veterinary and Pharmaceutical Sciences Brno, Brno, Czech \\ Republic
}

\begin{abstract}
The distribution, variability and host specificity of species of Babesia Starcovici, 1893 were studied in questing ticks collected on the northwestern edge of the Pannonian Basin in the south-easternmost part of the Czech Republic and in western Slovakia. The area is characterised by relatively natural floodplain habitats and the sympatric occurrence of three tick species possessing wide host spectra, namely Ixodes ricinus (Linnaeus), Dermacentor reticulatus (Fabricius) and Haemaphysalis concinna Koch. Analysis was carried out on 1,408 I. ricinus, 2,999 D. reticulatus and $150 \mathrm{H}$. concinna altogether, collected from 59 localities. We documented the presence of Babesia spp. not only in I. ricinus but also in H. concinna in the Czech Republic. Two isolates from I. ricinus were classified as B. venatorum Herwaldt, Cacciò, Gherlinzoni, Aspöck, Slemenda, Piccaluga, Martinelli, Edelhofer, Hollenstein, Poletti, Pampiglione, Löschenberger, Tura et Pieniazek, 2003 (formerly determined as Babesia sp. EU1), which is a zoonotic parasite and can cause human babesiosis. The rest of our amplicons were very similar to B. canis (Piana et Galli-Valerio, 1895), which is usually transmitted by $D$. reticulatus. Despite the huge amount of examined samples, all $D$. reticulatus ticks were Babesia-free. Due to this finding, we did not consider our obtained isolates to be $B$. canis, but other closely related species possessing a similar sequence of the studied portion of 18S rDNA. Although this genetic marker is most frequently used in PCR-based diagnostic methods of babesias, its low variability compromises its reliability in studies based only on this marker.
\end{abstract}

Keywords: host-specificity, piroplasms, species diagnosis, 18S rRNA

This article contains supporting information (Table S1) online at http://folia.paru.cas.cz/supp1/2017-64-028.pdf

The members of the genus Babesia Starcovici, 1893 are tick-transmitted apicomplexan haemoparasites. Their life cycle includes sexual reproduction within the tick vector, whereas merozoites are formed in the erythrocytes of their vertebrate host (Mehlhorn and Schein 1985). Babesiosis has a heterogeneous clinical picture corresponding to immune-mediated haemolytic anaemia. Some species of Babesia have zoonotic potential, three of them are present in Europe and they are transmitted by Ixodes ricinus (Linnaeus). Babesia divergens (M'Fadyean et Stockman, 1911) is the most common zoonotic species in Europe (Gray et al. 2010), with cattle as a natural host. Human infections with $B$. divergens have been reported from Great Britain, France, Ireland, Spain, Sweden and the former USSR (Zintl et al. 2003); so far more than forty clinical cases in Europe have been confirmed (Hildebrandt et al. 2013).
The most recently described zoonotic species is $B$. venatorum Herwaldt, Cacciò, Gherlinzoni, Aspöck, Slemenda, Piccaluga, Martinelli, Edelhofer, Hollenstein, Poletti, Pampiglione, Löschenberger, Tura et Pieniazek, 2003 (formerly described also as Babesia sp. EU1), infecting roe deers and reported in Europe from Belgium, France, Italy, the Netherlands, Poland, Slovenia and Switzerland (Duh et al. 2005, Casati et al. 2006, Cieniuch et al. 2009, Wielinga et al. 2009, Cassini et al. 2010, Gray et al. 2010, Lempereur et al. 2011, Reis et al. 2011).

Babesia microti (Franca, 1912) is prevalent in ticks across the whole Europe, but the only autochthonous case in Europe was confirmed in 2006 (Hildebrandt et al. 2007). Surveys in Germany, Poland and Switzerland have proved the presence of antibodies against B. microti in, 5.4\% (25 of 467$), 5 \%$ ( 2 of 39$)$ and $1.5 \%$ (5 of 366) humans exposed

Address for correspondence: P. Široký, Department of Biology and Wildlife Diseases, Faculty of Veterinary Hygiene and Ecology, University of Veterinary and Pharmaceutical Sciences Brno, Palackého 1946/1, Brno 612 42, Czech Republic. Phone: 727954 256; Fax 541 562 631; E-mail: sirokyp@vfu.cz 
to tick bites, respectively (Foppa et al. 2002, Hunfeld et al. 2002, Chmielewska-Badora et al. 2012). These studies suggest the possibility of more undiagnosed babesiosis cases in Europe. Infection rates in ticks are usually low and range from 0.9 to $20 \%$ (Hildebrandt et al. 2013).

Babesia venatorum represents a nomenclatural problem since the original description by Herwaldt et al. (2003), who provided a molecular genetic characterisation, computer-generated images of a new Babesia species on a Giemsa-stained smear, a catalogue accession number (2002/9) of three smears deposited in Upper Austrian Museum Linz, and also a complete etymological 'derivatio nominis'. Remarkably, after such a quite useful description, the authors stated that 'this description is not a description' and suggested a candidatus status instead (Herwaldt et al. 2003). We think that the paper has properties of valid description of the new species in spite of the authors' statement of its provisional status, and we consider $B$. venatorum to be a valid species.

Regarding the Czech Republic, B. venatorum was first documented from $I$. ricinus collected near Ostrava in 2010 (Venclíková et al. 2015) and B. microti was confirmed by Rudolf et al. (2005) in the nymphs of I. ricinus collected in South Moravia at the southeast of the Czech Republic. Despite the presence of zoonotic species of Babesia, no autochthonous case of human babesiosis has been reported in the Czech Republic so far. A B. microti infection imported from the USA was the only case of human babesiosis reported in the Czech Republic (Nohýnková et al. 2002).

Babesiosis also occurs in domestic animals such as cattle namely $B$. bovis (Babès, 1888), B. bigemina (Smith et Kilborne, 1893) and $B$. divergens; the last species causes serious economic losses (Zintl et al. 2003), and dogs - B. canis (Piana et Galli-Valerio, 1895) and B. gibsoni (Patton, 1910) (see Uilenberg et al. 1989, Boozer and Macintire 2003). Canine babesiosis caused by B. canis is considered an emerging disease spreading with its vector Dermacentor reticulatus (Fabricius) (Zygner et al. 2009). Clinical cases of babesiosis caused by $B$. canis are milder and have been reported from countries neighbouring with the Czech Republic, such as Austria, Germany, Poland and Slovakia (Zahler et al. 2000, Chandoga et al. 2002, Adaszek and Winiarczyk 2008, Majláthová et al. 2011, Silaghi et al. 2011). The more pathogenic $B$. gibsoni has been recently reported from Slovakia (Víchová et al. 2016). The distribution of species of Babesia infecting dogs was reviewed by Solano-Gallego et al. (2016).

The present study was realised in the western part of the Pannonian Basin along the lower courses and confluence of the rivers Dyje and Morava in the Czech Republic and to the lowlands along the River Morava in western Slovakia. It is an area with the sympatric occurrence of three tick species - Ixodes ricinus, the vector of zoonotic babesias, Dermacentor reticulatus, the vector of B. canis, and the less studied Haemaphysalis concinna Koch. This makes this area an ideal model for the study of vector capabilities of various tick species. Despite this situation, B. microti is the only babesia so far reported from this region (Rudolf et al. 2005). This study aims to fill the gaps in our knowledge of the variability, host specificity and distribution of babesias in this area.

\section{MATERIAL AND METHODS}

\section{Tick sampling}

The ticks were collected by flagging (Sonenshine 1993) with a $1 \mathrm{~m} \times 1 \mathrm{~m}$ white denim flag in southern Moravia and western Slovakia, during the spring and autumn season of 2009-2011. The collected ticks were placed in plastic tubes with $96 \%$ pure ethanol and stored at room temperature. The sex and species determination of the ticks was performed using the identification key by Nosek and Sixl (1972). We used 150 H. concinna, 1,408 I. ricinus and 2,999 D. reticulatus ticks for further analysis, altogether collected from 59 localities ( 35 in the Czech Republic and 24 in Slovakia - Table S1).

\section{DNA extraction}

The total genomic DNA from I. ricinus and D. reticulatus was extracted by alkaline hydrolysis, using the method of Rijpkema et al. (1996), modified by Kubelová et al. (2011). The ticks were airdried and placed in $1.5 \mathrm{ml}$ test tubes with $500 \mu 1$ of $0.36 \mathrm{M}$ ammonium hydroxide. The ticks were crushed with sterile single-use plastic pipette tips and boiled at $100^{\circ} \mathrm{C}$ for $30 \mathrm{~min}$ in closed tubes and another $\mathrm{ca} 30 \mathrm{~min}$ in opened tubes, to evaporate any remaining ammonia until $100 \mu \mathrm{l}$ of lysate left. Tubes containing only ammonium hydroxide were included as negative controls in each of the isolation runs. Negative controls were checked for presence of DNA to detect contamination during extraction process.

DNA from $H$. concinna (originally used in a different study) was isolated by the modified phenol-chloroform method using guanidine isothiocyanate (GT) (Chomczynski and Sacchi 2006). The ticks were also air-dried, placed into $1.5 \mathrm{ml}$ test tubes and crushed in $150 \mu \mathrm{l}$ of Tris-EDTA buffer. After homogenisation, $450 \mu \mathrm{l}$ of GT was added. Precipitation of the proteins was achieved by adding $100 \mu \mathrm{l}$ of chloroform and centrifugation. Supernatant was placed into a new test tube with $600 \mu \mathrm{l}$ of 2-propanol, samples were placed into freezers at $-20^{\circ} \mathrm{C}$ over night. The next day samples were centrifuged in $4{ }^{\circ} \mathrm{C}$ and the liquid was spilled. Then $800 \mu 1$ of $70 \%$ ethanol was added and after centrifuging the liquid was displaced again. In the last step the pellet was resuspended in $50 \mu 1$ of PBS buffer and the samples were incubated at $55^{\circ} \mathrm{C}$ for $15 \mathrm{~min}$. All obtained samples were stored at $-20^{\circ} \mathrm{C}$.

\section{PCR analysis}

The PCR diagnosis consisted of a nested PCR reaction. An $c a$ 790 bp long portion of $18 \mathrm{~S}$ rDNA was amplified by nested PCR according to the protocol established by Jefferies et al. (2007) and modified by Kubelová et al. (2011), while the annealing temperature was lowered. We used primers BTF1 (5'-GGCTCATTACAACAGTTATAG-3') and BTR1 (5'-CCCAAAGACTTTGATTTCTCTC-3') for the first step, followed by BTF2 (5'-CCGTGCTAATTGTAGGGCTAATAC-3') and BTR2 (5'-GGACTACGACGGTATCTGATCG-3') for the second step. The mixture for PCR reaction (volume $25 \mu \mathrm{l}$ ) was composed of $12.5 \mu \mathrm{l}$ of Combi PPP MasterMix (TopBio, Vestec, Czech Republic), $9.5 \mu$ of PCR $\mathrm{H}_{2} \mathrm{O}$ (TopBio), $1 \mu \mathrm{l}$ of each primer (KRD, Praha, Czech Republic) and $1 \mu$ of template DNA. The initial denaturation at $94^{\circ} \mathrm{C}$ for $3 \mathrm{~min}$ was followed by 35 cycles com- 


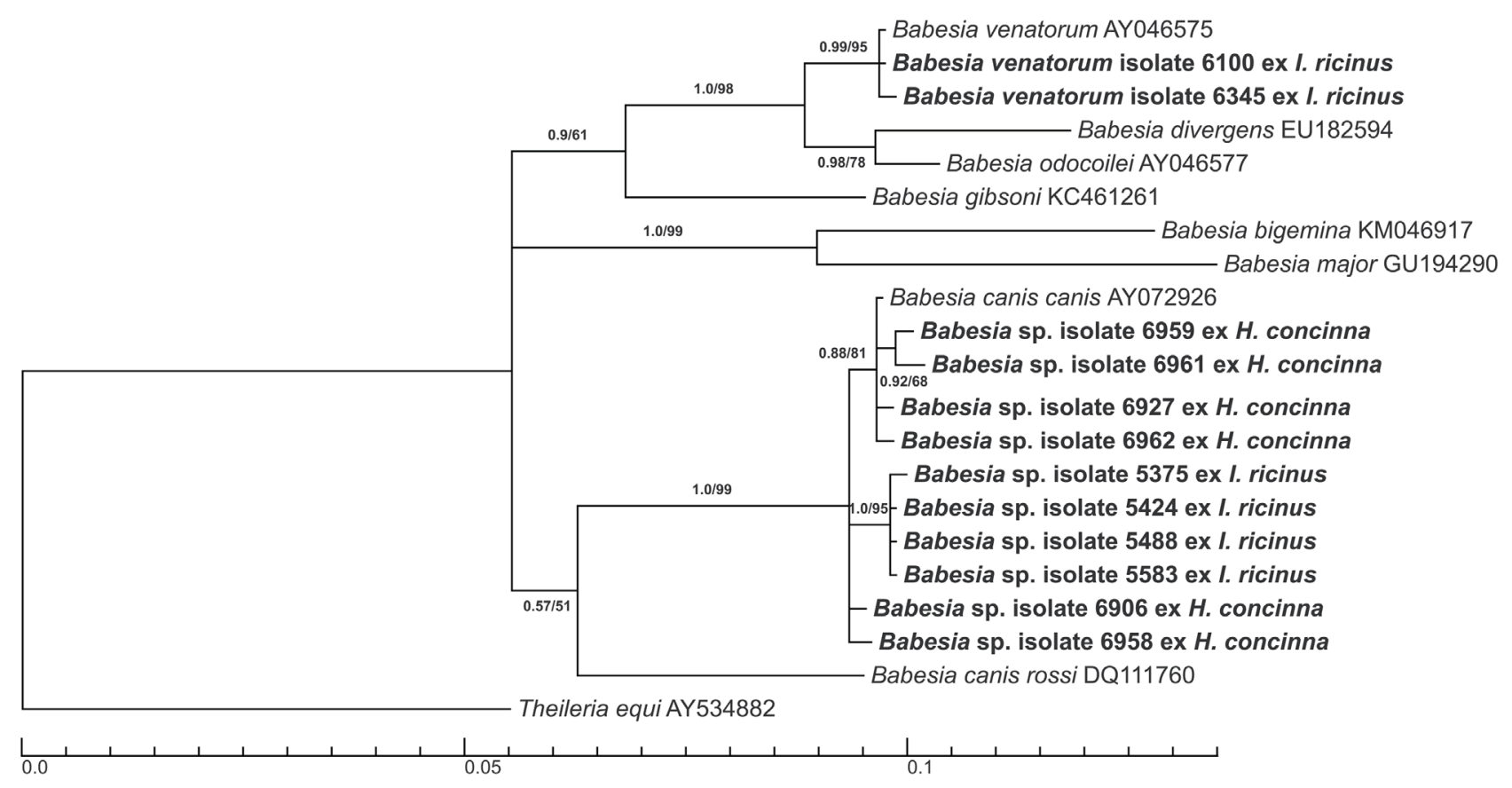

Fig. 1. Phylogenetic tree of Babesia spp. as revealed by Bayesian analysis based on $773 \mathrm{bp}$ long alignment of 18S rDNA. Branch lengths indicate expected numbers of substitutions per nucleotide site. Maximum Likelihood (ML) tree provided identical topology. Numbers along branches indicate Bayesian posterior probabilities/percent bootstrap values as obtained by ML analysis (posterior probabilities $<0.8$ and bootstrap values $<50$ not shown). Branches with posterior probabilities $<0.5$ and/or bootstrap values $<50$ were collapsed. Isolates sequenced in this study are highlighted in bold.

posed of 1 min of denaturation at $94^{\circ} \mathrm{C}$, annealing at $58^{\circ} \mathrm{C}$ for $1 \mathrm{~min}$, and extension at $72^{\circ} \mathrm{C}$ for $2 \mathrm{~min}$. The final extension at $72{ }^{\circ} \mathrm{C}$ lasted $7 \mathrm{~min}$. Positive (B. canis DNA isolated from $D$. reticulatus) and negative (Ultra Pure PCR $\mathrm{H}_{2} \mathrm{O}$ ) controls were included in each reaction.

The acquired positive PCR products were purified using a Gel/PCR Fragments Extraction Kit (Geneaid, New Taipei City, Taiwan) according to the manufacturer's protocol and sent for sequencing to Macrogen (Amsterdam, the Netherlands).

\section{Sequence analysis}

The obtained sequences were aligned in MEGA6 (Tamura et al. 2013) and compared to the GenBank database using the BLAST algorithm (Altschul et al. 1990). The final alignment with additional sequences from GenBank (see Fig. 1 for Acc. Nos.) consisted of $773 \mathrm{bp}$. Akaike information criterion was used to identify the most appropriate model of nucleotide substitution. Bayesian inference analysis was carried out in the Mr.Bayes 3.2.6 plugin in Geneious 9.1.5 (Ronquist and Huelsenbeck 2003, Kearse et al. 2012) with the GTR $+\mathrm{G}+\mathrm{I}$ model for $10^{7}$ generations, with phylogenies sampled every 1,000 generations. The trees were summarised after removing burn-in (1,000 trees). Maximum Likelihood (ML) phylogenetic analysis was conducted by PhyML 2.2.0 plugin in Geneious 9.1.5 (Guindon and Gascuel 2003, Kearse et al. 2012) with the GTR $+\mathrm{G}+\mathrm{I}$ model and parameters estimated from the data; nodal supports were generated with 1,000 bootstrap replicates. The resulting trees including Theileria equi (Laveran, 1901) as an outgroup were visualised using TreeGraph 2.12.0 (Stöver and Müller 2010).

\section{RESULTS AND DISCUSSION}

The DNA of Babesia spp. was detected in 22 (1.6\%) of analysed Ixodes ricinus and in six (4\%) of Haemaphysalis concinna. We found no DNA of any piroplasm in Dermacentor reticulatus. The BLAST analysis of the obtained sequences showed that two of our products from $I$. ricinus were $100 \%$ identical to the $B$. venatorum sequence from GenBank (Acc. No. AY046575), whereas the remaining sequences either from $I$. ricinus or $H$. concinna were most similar to the GenBank records of $B$. canis. Those of our sequences reported hereafter as $B$. canis-like correspond with $99 \%$ similarity to nucleotides 162 to 953 of the published B. canis 18S rDNA (GenBank Acc. No. AY072926). Babesia venatorum-positive samples (GenBank Acc. Nos. KX857479 and KX857480) were collected at two localities near the Nové Mlýny Dam Lake on the Dyje River in the Czech Republic. The DNA of B. canis-like (GenBank Acc. Nos. for each unique sequence in Table 1) was found at nine locations in the Czech Republic and two locations in Slovakia (Table S1).

A comparison of our sequences with the GenBank record (Acc. No. AY072926) of B. canis showed five single nucleotide polymorphisms (Table 1). Sequences from isolates from $I$. ricinus can be clearly distinguished from isolates from $H$. concinna as they contain $\mathrm{T}, \mathrm{A}$, and $\mathrm{G}$ on positions 399,717 and 888 , respectively, whereas isolates from $H$. concinna contain $\mathrm{C}, \mathrm{G}$ and $\mathrm{A}$ on these positions. Further variability is located on positions 606-607, which is used to differentiate between two genotypes ' $\mathrm{A}$ ' (nucle- 
Table 1. Sequence variability and GenBank accession numbers of Babesia canis-like isolates.

\begin{tabular}{lllllllll}
\hline & & & \multicolumn{3}{c}{$\begin{array}{c}\text { Nucleotides on selected } \\
\text { positions }\end{array}$} \\
\hline $\begin{array}{llllllll}\text { GenBank } \\
\text { Acc. Nos. }\end{array}$ & Isolate & Host & 399 & 606 & 607 & 717 & 888 \\
\hline & $\begin{array}{l}\text { Babesia canis } \\
\text { (Piana et Gal- }\end{array}$ & dog & & & & & \\
AY072926 & li-Valerio, 1895) & C & G & A & G & A \\
& Ixodes ricinus & T & A & G & A & G \\
KX857481 & 5375 & (Linnaeus) & & & & & \\
KX857482 & 5424 & I. ricinus & T & A & G & A & G \\
KX857483 & 5488 & I. ricinus & T & A & G & A & - \\
KX857484 & 5583 & I. ricinus & T & A & G & A & - \\
KX857472 & 6959 & $\begin{array}{l}\text { Haemaphysalis } \\
\text { concinna Koch }\end{array}$ & C & G & A & G & A \\
KX857473 & 6927 & H. concinna & C & G & A & G & A \\
KX857474 & 6906 & H. concinna & C & A & G & G & A \\
KX857475 & 6961 & H. concinna & C & G & A & G & A \\
KX857476 & 6962 & H. concinna & C & G & A & G & A \\
KX857477 & 6958 & H. concinna & C & A & G & G & A \\
\hline
\end{tabular}

otides A-G) and 'B' (nucleotides G-A) of B. canis. Four of our isolates from $H$. concinna correspond to genotype ' $\mathrm{B}$ ', which is described as being the more pathogenic of the two (Adaszek and Winiarczyk 2008). All isolates from I. ricinus and two isolates from $H$. concinna have nucleotides A-G on these positions, so they belong to genotype 'A'.

Detection of isolates with $18 \mathrm{~S}$ rDNA very similar to $B$. canis is surprising, since no case of autochthonous canine babesiosis caused by this species has been described in the Czech Republic so far. Canine babesiosis is widespread in neighbouring countries. The first clinical case in Slovakia was described almost 15 years ago (Chandoga et al. 2002). Since then many clinical cases have been reported (Majláthová et al. 2011, Cook and Swann 2016). A prevalence of up to $50 \%$ in questing ticks was confirmed in Hungary (Hornok et al. 2016), and up to $11 \%$ in Poland (Zygner et al. 2008). A molecular study showed a more than $25 \%$ prevalence of $B$. canis in the blood of asymptomatic dogs in Poland (Welc-Falęciak et al. 2009). Kubelová et al. (2011) studied the distribution of B. canis in $D$. reticulatus in the Danubian Lowland and documented the westernmost $B$. canis-positive D. reticulatus near Gabčíkovo Waterworks close to Bratislava.

Despite the number of examined $D$. reticulatus, the definitive host of $B$. canis, originating from the studied area, we did not find any of them to contain Babesia DNA. The absence of $B$. canis in examined samples could be caused by lower concentration of Babesia DNA in our samples. Nevertheless, B. canis-positive samples isolated from $D$. reticulatus collected in year 2009 and extracted with the same method are still used in our laboratory as Babesia-positive control with very high concentration, so we do not expect low yield due to this extraction method. In an earlier study, Konvalinová et al. (2012) described a $12 \%$ prevalence of anti- $B$. canis antibodies among 41 asymptomatic PCR-negative dogs from district Břeclav and Lanžhot with no history of travelling abroad. The geographic occurrence of these serologically positive dogs corresponds with our findings of Babesia-positive ticks. It is notable that $B$. canis-like infection has been discovered in other than the known definitive tick host species. The phenomenon of the presence of $B$. canis in other tick species than $D$. reticulatus has previously been reported. Cieniuch et al. (2009) described the presence of B. canis from I. ricinus in Poland and Tomanović et al. (2012) proved the presence of $B$. canis in $H$. concinna in Serbia. However, the authors amplified a sequence (146 bp) of $18 \mathrm{~S}$ rDNA, which was too short for reliable species diagnosis and provided no details about homology with GenBank records.

Infection by $B$. canis in a dog with clinical signs of babesiosis and the presence of large babesias has also been reported in Norway, out of the range of $D$. reticulatus (see Øines et al. 2010). Possible explanations are as follows: (1) the introduction of an infected vector, (2) the undisclosed travelling history of the dog, or (3) infection by another, nearly identical species of Babesia, transmitted by another tick vector. The resolution of $18 \mathrm{~S}$ rDNA between various species of Babesia is generally very low; nevertheless, fragments of $18 \mathrm{~S}$ rDNA are clearly most available for sequence comparison. From a species diagnostics point of view, a multi-gene approach would be more appropriate. Accordingly, we tried to obtain complete $18 \mathrm{~S}$ sequences and sequences of the cox 1 gene from our positive samples, but we were not successful, most probably due to the age and inappropriate storage of the isolated DNA.

The species determination of babesias is still complicated in spite of the growing number of available sequence data and an improvement in PCR-based methods. Taking into account the absence of Babesia-positive D. reticulatus, the absence of clinical cases of canine babesiosis caused by $B$. canis, and the lower reliability of $18 \mathrm{~S}$ rDNA in the species diagnosis of babesias, we might suggest that our isolates are not $B$. canis, but another very closely related species possessing a similar studied portion of sequence of $18 \mathrm{~S}$ rDNA. Due to the presence of seropositive dogs in the same geographic area as Babesia-positive ticks, we cannot exclude the possibility of a cross-immunity reaction between $B$. canis and Babesia spp. from other tick species.

Acknowledgements. The authors would like to thank Christopher Steer for the language correction of this paper. The authors would also like to acknowledge Lenka Pokorná for her invaluable laboratory work. This work was financially supported by the Internal Grant Agency of the University of Veterinary and Pharmaceutical Sciences Brno, project no. 11/2014/FVHE, and by the Czech Health Research Council (project AZV no. 16-33934A). I.P. and P.S. have been financially supported by the Ministry of Education, Youth, and Sports of the Czech Republic under the project CEITEC 2020 (LQ1601). 


\section{REFERENCES}

ADASZEK L., WinIARCZYK S. 2008: Molecular characterization of Babesia canis canis isolates from naturally infected dogs in Poland. Vet. Parasitol. 152: 235-241.

Altschul S.F., Gish W., Miller W., Myers E.W., Lipman D.J. 1990: Basic local alignment search tool. J. Mol. Biol. 215: 403-410.

Boozer A.L., Macintire D.K. 2003: Canine babesiosis. Vet. Clin. North Am. Small Anim. Pract. 33: 885-904, viii.

Casati S., Sager H., Gern L., Piffaretti J.-C. 2006: Presence of potentially pathogenic Babesia sp. for human in Ixodes ricinus in Switzerland. Ann. Agr. Env. Med. 13: 65-70.

Cassini R., Bonoli C., Montarsi F., Tessarin C., Marcer F., Galuppi R. 2010: Detection of Babesia EU1 in Ixodes ricinus ticks in northern Italy. Vet. Parasitol. 171: 151-154.

Chandoga P., Goldová M., Baranová D., KozáK M. 2002: First cases of canine babesiosis in the Slovak Republic. Vet. Rec. 150: $82-84$

Chmielewska-Badora J., Moniuszko A., Żukiewicz-SobCzak W., Zwoliński J., Piątek J., Pancewicz S. 2012: Serological survey in persons occupationally exposed to tick-borne pathogens in cases of co-infections with Borrelia burgdorferi, Anaplasma phagocytophilum, Bartonella spp. and Babesia microti. Ann. Agr. Env. Med. 19: 271-274.

Chomczynski P., SACCHi N. 2006: The single-step method of RNA isolation by acid guanidinium thiocyanate-phenol-chloroform extraction: twenty-something years on. Nat. Protoc. 1: $581-585$.

Cieniuch S., Stańczak J., Ruczaj A. 2009: The first detection of Babesia EU1 and Babesia canis canis in Ixodes ricinus ticks (Acari, Ixodidae) collected in urban and rural areas in northern Poland. Pol. J. Microbiol. 58: 231-236.

Cook S., Swann J.W. 2016: Canine babesiosis: autochthonous today, endemic tomorrow? Vet. Rec. 178: 417-419.

Duh D., Petrovec M., Avsic-Zupanc T. 2005: Molecular characterization of human pathogen Babesia EU1 in Ixodes ricinus ticks from Slovenia. J. Parasitol. 91: 463-465.

Foppa I.M., Krause P.J., Spielman A., Goethert H., Gern L., Brand B., Telford, S.R. 2002: Entomologic and serologic evidence of zoonotic transmission of Babesia microti, eastern Switzerland. Emerg. Infect. Dis. 8: 722-726.

Gray J., Zintl A., Hildebrandt A., Hunfeld K.-P., Weiss L. 2010: Zoonotic babesiosis: overview of the disease and novel aspects of pathogen identity. Ticks Tick-Borne Dis. 1: 3-10.

Guindon S., Gascuel O. 2003: A simple, fast, and accurate algorithm to estimate large phylogenies by maximum likelihood. Syst. Biol. 52: 696-704.

Herwaldt B.L., Cacciò S., Gherlinzoni F., Aspöck H., Slemenda S.B., Piccaluga P.P., Martinelli G., Edelhofer R., Hollenstein U., Poletti G., Pampiglione S., LöschenBerger K., Tura S., Pieniazek N.J. 2003: Molecular characterization of a non-Babesia divergens organism causing zoonotic babesiosis in Europe. Emerg. Infect. Dis. 9: 942-948.

Hildebrandt A., Gray J.S., Hunfeld K.-P. 2013: Human babesiosis in Europe: what clinicians need to know. Infection 41: 1057-1072.

Hildebrandt A., Hunfeld K.-P., Baier M., Krumbholz A., Sachse S., Lorenzen T., Kiehntopf M., Fricke H.-J., STRAube E. 2007: First confirmed autochthonous case of human Babesia microti infection in Europe. Eur. J. Clin. Microbiol. Infect. Dis. 26: 595-601.

Hornok S., Kartali K., Takács N., Hofmann-Lehmann R. 2016: Uneven seasonal distribution of Babesia canis and its two $18 \mathrm{~S}$ rDNA genotypes in questing Dermacentor reticulatus ticks in urban habitats. Ticks Tick-Borne Dis. 7: 694-697.

Hunfeld K.-P., Lambert A., Kampen H., Albert S., Epe C., Brade V., Tenter A.M. 2002: Seroprevalence of Babesia infections in humans exposed to ticks in midwestern Germany. J. Clin. Microbiol. 40: 2431-2436.
JefFeries R., Ryan U.M., Irwin P.J. 2007: PCR-RFLP for the detection and differentiation of the canine piroplasm species and its use with filter paper-based technologies. Vet. Parasitol. 144: $20-27$.

Kearse M., Moir R., Wilson A., Stones-Havas S., Cheung M., Sturrock S., Buxton S., Cooper A., Markowitz S., Duran C., Thierer T., Ashton B., Mentuies P., DrumMOND A. 2012: Geneious Basic: an integrated and extendable desktop software platform for the organization and analysis of sequence data. Bioinformatics 28: 1647-1649.

Konvalinová J., Rudolf I., Šikutová S., Hubálek Z., SvoBodová V., Svoboda M. 2012: Contribution to canine babesiosis in the Czech Republic. Acta Vet. Brno 81: 91-95.

Kubelová M., Tkadlec E., Bedná Ř M., Roubalová E., Široký P. 2011: West-to-east differences of Babesia canis canis prevalence in Dermacentor reticulatus ticks in Slovakia. Vet. Parasitol. 180: 191-196.

Lempereur L., De Cat A., Caron Y., Madder M., ClaereBout E., Saegerman C., Losson B. 2011: First molecular evidence of potentially zoonotic Babesia microti and Babesia sp. EU1 in Ixodes ricinus ticks in Belgium. Vector-Borne Zoonotic Dis. 11: $125-130$.

Majláthová V., Majláth I., Víchová B., Gulová I., Derdáková M., Sesztáková E., PeŤKo B. 2011: Polymerase chain reaction confirmation of Babesia canis canis and Anaplasma phagocytophilum in dogs suspected of babesiosis in Slovakia. Vector-Borne Zoonotic Dis. 11: 1447-1451.

Mehlhorn H., Schein E. 1985: The piroplasms: life cycle and sexual stages. Adv. Parasitol. 23: 37-103.

Nohýnková E., Kubek J., Měsťánková O., Chalupa P., HubÁLEK Z. 2002: [A case of Babesia microti imported into the Czech Republic from the USA]. Čas. Lék. Česk. 142: 377-381. (In Czech.)

Nosek J., SixL W. 1972: Central-European ticks (Ixodoidea). Key for determination. Mitt. Abt. Zool. Landesmus Joanneum 1: 61-92.

Øines Ø., Storli K., Brun-Hansen H. 2010: First case of babesiosis caused by Babesia canis canis in a dog from Norway. Vet. Parasitol. 171: 350-353.

Reis C., Cote M., Paul R.E.L., Bonnet S. 2011: Questing ticks in suburban forest are infected by at least six tick-borne pathogens. Vector-Borne Zoonotic Dis. 11: 907-916.

Rijpkema S., Golubić D., Molkenboer M., Verbeek-De Kruif N., SChellekens J.F. 1996: Identification of four genomic groups of Borrelia burgdofreri sensu lato in Ixodes ricinus ticks collected in a Lyme borreliosis endemic region of northern Croatia. Exp. Appl. Acarol. 20: 23-30.

Ronquist F., Huelsenbeck J.P. 2003: MrBayes 3: Bayesian phylogenetic inference under mixed models. Bioinformatics 19: $1572-1574$

Rudolf I., Golovchenko M., Sikutová S., Rudenko N., Grubhoffer L., Hubálek Z. 2005: Babesia microti (Piroplasmida: Babesiidae) in nymphal Ixodes ricinus (Acari: Ixodidae) in the Czech Republic. Folia Parasitol. 52: 274-276.

Silaghi C., Hamel D., Pfister K. \& Rehbein S. 2011. Babesia species and co-infection with Anaplasma phagocytophilum in free-ranging ungulates from Tyrol (Austria). Wien. Tierarztl. Monatsschr. 98: 268-274.

Solano-Gallego L., Sainz A., Roura X., Estrada-Pena A., Miro G. 2016: A review of canine babesiosis: the European perspective. Parasites Vectors 9: 336

Sonenshine D.E. 1993: Biology of Ticks, Vol. 2. Oxford University Press, NY, xvii+465 pp.

StÖVer B.C., Müller K.F. 2010: TreeGraph 2: Combining and visualizing evidence from different phylogenetic analyses. BMC Bioinformatics 11: 7. 
Tamura K., Stecher G., Peterson D., Filipski A., Kumar S. 2013: MEGA6: Molecular Evolutionary Genetics Analysis Version 6.0. Mol. Biol. Evol. 30: 2725-2729.

Tomanović S., Chochlakis D., Radulović Ž., Milutinović M., Ćakić S., Mihaljica D., Tselentis Y., Psaroulaki A. 2012: Analysis of pathogen co-occurrence in host-seeking adult hard ticks from Serbia. Exp. Appl. Acarol. 59: 367-376.

Uilenberg G., Franssen F.F., Perié N.M., Spanjer A.A. 1989: Three groups of Babesia canis distinguished and a proposal for nomenclature. Vet. Q. 11: 33-40.

Venclíková K., Mendel J., Betášová L., Hubálek Z., Rudolf I. 2015: First evidence of Babesia venatorum and Babesia capreoli in questing Ixodes ricinus ticks in the Czech Republic. Ann. Agr. Env. Med. 22: 212-214.

Víchová B., Horská M., Blañarová L., Švihran M., AnDERSSON M., PeŤKo B. 2016: First molecular identification of Babesia gibsoni in dogs from Slovakia, central Europe. Ticks Tick-Borne Dis. 7, 54-59.

Welc-Falęciak R., Roo A., Siński E., Bajer A. 2009: Babesia canis and other tick-borne infections in dogs in Central Poland. Vet. Parasitol. 166: 191-198.
Wielinga P.R., Fonville M., Sprong H., GaAsenbeek C., Borgsteede F., van der Giessen J.W.B. 2009: Persistent detection of Babesia EU1 and Babesia microti in Ixodes ricinus in the Netherlands during a 5-year surveillance: 2003-2007. Vector-Borne Zoonotic Dis. 9: 119-122.

Zahler M., Steffen T., Lutz S., Hähnel W.-C., Rinder H., Gotнe R. 2000: Babesia canis and Dermacentor reticulatus in Munich: a new endemic focus in Germany. Tierarztl. Prax. Ausgabe K Kleintiere Heimtiere 28: 116-120.

Zintl A., Mulcahy G., Skerrett H.E., Taylor S.M., Gray J.S. 2003: Babesia divergens, a bovine blood parasite of veterinary and zoonotic importance. Clin. Microbiol. Rev. 16: 622636.

ZyGner W., Górski P., WęDrychowicz H. 2009: New localities of Dermacentor reticulatus tick (vector of Babesia canis canis) in central and eastern Poland. Pol. J. Vet. Sci. 12: 549-555.

Zygner W., Jaros S., WęDrychowicz H. 2008: Prevalence of Babesia canis, Borrelia afzelii, and Anaplasma phagocytophilum infection in hard ticks removed from dogs in Warsaw (central Poland), Vet. Parasitol. 153: 139-142.

Cite this article as: Rybářová M., Honsová M., Papoušek I., Široký P. 2017: Variability of species of Babesia Starcovici, 1893 in three sympatric ticks (Ixodes ricinus, Dermacentor reticulatus and Haemaphysalis concinna) at the edge of Pannonia in the Czech Republic and Slovakia. Folia Parasitol. 64: 028. 